Milan Palević ${ }^{1}$

University of Kragujevac

Faculty of Law Kragujevac, Serbia

Bojan Milisavljević ${ }^{2}$

University of Belgrade

Faculty of Law Belgrade, Serbia

\section{Žaklina Spalević ${ }^{3}$}

Singidunum University

Belgrade, Serbia
SCIENTIFIC REVIEW ARTICLE doi:10.5937/ekonomika1904063P

Received: Jul 09. 2019.

Accepted: September 19. 2019.

\title{
ACTUS REUS OF GENOCIDE AND TYPES OF GENOCIDAL DESTRUCTION
}

\begin{abstract}
A model of genocidal destruction implies the manner in which genocide is carried out. Questions deriving from my fundamental point at issue are whether mass killings, cultural repressions, starvation, prevention of birth, politicide constitute genocide or whether genocide, in that sense, is limited to biological or physical destruction of a protected group? The post-war development of international law, especially as a result of the adoption of the Universal Declaration of Human Rights and Convention on Human Rights, and a number of conventions related to human rights, as well as jurisprudence of the two tribunals, signaled the existence of a wider concept of a customary-legal concept of genocide, that could intrinsically involve a prerogative of cultural destruction. The modern theorethical views have expressed such a tendency. From a "de lege ferenda" perspective, this could be interpreted and understood as a positive tendency, but at the same time it is questionable from the perspective of a legislative and formallegal character of the Convention on the Prevention and Punishment of the Crime of Genocide. This paper elaborates material acts of genocide and their position within the concept of genocide considering the controversies of the models of genocidal destruction.
\end{abstract}

Key words: genocide, convention, actus reus of genocide, forms of destruction.

JEL classification: K14, K33, K38.

\section{ACTUS REUS ГЕНОЦИДА И ВРСТЕ ГЕНОЦИДНОГ УНИШТЕЊА}

\section{Апстракт}

Модел геноцидног уништена подразумева начин на који се геноцид врии. Изведена из тог основног су и питана да ли су масовна убиства, културне

\footnotetext{
${ }^{1}$ mpalevic@jura.kg.ac.rs

${ }^{2}$ bojan@ius.bg.ac.rs

${ }^{3}$ zspalevic@singidunum.ac.rs
} 
репресије, изгладниване, превенција рађана или политоцид све начини извриена геноцида или се геноиид у том погледу тимитира на биолошко односно бизичко уништенезаштићенегрупе. Послератниразвојмеђународног права, пре свега декларације и Пактови УН-а, те бројне конвенције везане за тьудска права као и судска пракса два трибунала, сигнализирали су постојане ширег обичајноправног кониепта геноцида који би у себи могао инволвирати и прерогативе културног уништена. У модерним теоријским схватанима испољена је слична тендениија. С аспекта de lege ferenda, то се може разумети и тумачити као позитивна тендениија, али је истовремено дискутабилно са становишта легислативног и конзервативног карактера Конвениије. У раду се елаборирају материјални акти геноцида и позиционирате истих унутар идејног концепта злочина геноцида у светлу контроверзи модела геноцидног униитеньа.

Клучне речи: геноцид, конвениија, асtиs rеиз геноцида,, облик уништена.

\section{Introduction}

On the day of its adoption the Convention on the Prevention and Punishment of the Crime of Genocide (Resolution 260 (III) at the UN General Assembly,1948) became the subject of numerous criticism and disputes. The criticism aimed at the Convention rests largely on the hypothesis that, due to failure to include cultural genocide and due to exclusion of political groups from the set of protected groups, its definition of genocide is too narrow to cover all cases of genocide, especially modern types of genocide. However, the viewpoint that the UN definition of genocide is too broad also seems legitimate. For example, a campaign against a "part of a group" causing "serious harm to physical and mental integrity of members" could encompass a large number of cases, and that type of ambiguity to a large extent blurs the concept of genocide, questions its distinctive attributes and contributes to the inapplicability of the Convention itself.

In the process of adoption of the Convention a question was raised as to whether the concept of genocide should be limited only to the physical and biological genocide or it should include cultural genocide, i.e. acts of spiritual destruction of the essential characteristics of a group. A part of the Resolution 96/1 provided support to the view on the normative sanctioning of cultural genocide, stating that "physical destruction of the group impoverishes humanity and deprives it of the cultural contribution of a given group." Pella and de Vabres held that "cultural genocide represented an undue extension of the notion of genocide and amounted to reconstituting the former protection of minorities (which was based on other conceptions) under cover of the term genocide". Lemkin in turn, made a decisive and uncompromising stand on the need for inclusion of cultural genocide in the criminal classification of the concept of genocide, seeing it as an initial litmus link in the complex process of suppression of the physical and spiritual integrity of protected groups, which certainly is a reasonable reason for the inclusion of cultural genocide in the formal definition of genocide. Socialist countries, led by the Soviet Union and some of the countries of Latin America and Asia, were particularly interested 
in the problem and were resolutely persistent in the inclusion of cultural genocide in the definition of the crime. The negative historical experiences of the last war were still fresh and provided representative evidence on the extent and consequences of Nazi barbarity directed to the devastation of the spiritual integrity of individual nations. Delegates from Ukraine, Belarus, Poland and Czechoslovakia presented numerous examples of this form of destruction. Representatives of Latin American countries reminded of the crimes of the colonial period, which they claimed to have been largely focused towards the "destruction of civilizational identity" of indigenous peoples, which was decisive in their almost complete disappearance from the area which they have inhabited for centuries. "The crime always begins with the destruction of religious and cultural symbols of the persecuted groups" said the delegate from Peru, "which is then taken as a pretext for its obvious mental inferiority" which in consequence leads to the physical destruction of those groups. In this discussion, representative from Pakistan said that the physical and cultural genocide have the same motives and the same object of destruction, whether it is about physical destruction, or destruction of specific characteristics of the group (Avramov, 1992, p. 80.). In his opinion, "cultural genocide is the goal, while physical genocide is only a means" (Avramov, 1992, p. 80.) of execution.

Representatives of the leading Western countries and some countries of the Asian continent had a completely opposite view. The US explicitly opposed any option that would include the establishment of such a form of genocide. The US delegate expressed the view that the preservation of culture is best achieved through freedom of thought and expression. France had also expressed reservation towards the concept of cultural genocide, arguing that cultural rights must be protected, but that the issue of protection of cultural heritage, and culture in general, falls within the scope of protection of fundamental human rights. The Iranian delegate, after pointing out that it would be necessary to specify the properties of a culture that enjoyed protection, asked an interesting question: "Do all cultures, even the most barbarous, deserve protection and does assimilation, that is the product of a civilized action of a country, also constitutes genocide?" Instead of answering he made a logical assumption that extreme interpretation of the given assumption can produce such an attitude by which "an opposition to a political party could also be described as cultural genocide"(Avramov, 1992, pp. 80-81.).

Finally, cultural genocide was after all excluded from the categorization of genocidal acts, with the argument that the concept is too vague and broad, and that it is the subject matter of basic human rights. The Commission for International Law supported the viewpoint of the authors of Convention. In the 1996 report it was pointed out: "As clearly shown during the drafting of the Convention, the destruction in question is the material destruction of a group only in the physical and biological meaning, not the destruction of the national, linguistic, religious, cultural or other identity of a special group. The national or religious element and the racial or ethnic element should be considered within the definition of the word 'destruction', which should be taken only in its material sense, its physical or biological sense" (Report of the International Law Commission 1996, p. 102, para 4). 


\section{Material acts of genocide}

As Aksar remarked, to consider an act as constituting the crime of genocide, there must be three elements present: commission (actus reus), the victimized group, and the intention (mens rea) (Aksar,.2003, p. 212.).

The crime of genocide presupposes some of the following acts that can be subsumed under the act of criminal offense (Article II Convention on the prevention and Punishment of the Crime Genocide):
a. Killing members of the group;
b. Causing serious bodily or mental harm to members of the group;
c. Deliberately inflicting on the group conditions of life calculated to bring about its physical destruction in whole or in part;
d. Imposing measures intended to prevent births within the group;
e. Forcibly transferring children of the group to another group.

Taken together these acts constitute actus reus or material element of the genocide..

\section{Killing members of the group}

Killing members of the group is certainly the most characteristic form of committing genocide and most befitting to its nature and purpose. Unlike the Convention, some of the leading authors in the field of genocide theory (Carmen, Cooper, Chuck, Jonasson et al.) consider "killing" as the only way to commit genocide. According to the meaning given by the Convention on Genocide, of which the French and English translations are equally authentic, "killing" must be interpreted as "killing members of the group committed with the intent to cause death" (Jones \&.Powles, 2005, p. 151). In fact the term "members of the group" should not be interpreted narrowly, in its literal grammatical sense, by which the act of killing must include at least two members of the group. Such a conclusion would be absurd and contrary to the logic of the concept of genocide and the protective nature of the Convention. The quantitative dimension of genocide belongs to the psychological, not material element of genocide. The key, then, is genocidal intent and its orientation towards the destruction of the group "fully or partially" and not the actual scope of destruction.

"Killing" is arguably distinguishable from other modes of violence and might be considered the definitive mode of genocide. Even if publicly outlawed, language, custom, and arts can survive in private. Starvation and other forms of imposing hardship on a given group may, but not necessarily, bring about annihilation, if designed to bring a group into submission (Straus,.2001, p. 364.). By contrast, ending life is an irreversible, direct, immediate, and unambiguous mode of annihilation. Victim's death as a consequence of killing is the ultimate act of irreversible character. It is the essential element of the act of killing. Unlike "killing" all other acts constituting actus reus of genocide, which do not lead to actual annihilation, only have a "genocidal potential". Accordingly, these could be stricto sensu, qualified as attempted genocide rather than acts of genocide per se. Unlike killing, premeditation is not strictly required but, as noted before the International 
Criminal Tribunal for Rwanda in case of Akayesu, by its constitutive physical elements, the very crime of genocide, necessarily entails premeditation (Trial Judgement, ICTR-964-T, International Criminal Tribunal for Rwanda,1998,)

\section{Causing serious bodily or mental harm to members of the group}

Causing serious bodily injury that resulted in the physical destruction of one or more members of the target group is considered a definitive physical form of execution of genocide. Opposite to that, such bodily injuries that do not have or cannot have deadly consequences as the end result will not be considered acts of genocide. In this case, these acts fall under crimes against humanity or torture. In the case of Eichmann, the Jerusalem district court found that serious bodily or mental harm to members of the group can be caused by "enslavement, starvation, deportation, persecution..., imprisonment in ghettos, concentration camps, in conditions whose ultimate goal is to cause their humiliation, deprivation of rights enjoyed as human beings, to suppress them and cause inhumane suffering and torture." According to the International Criminal Tribunal for Rwanda (ICTR) "serious bodily or mental harm" includes torture, inhuman or degrading treatment and persecution, but is not limited to them (Trial Judgement, ICTR-96-4-T, International Criminal Tribunal for Rwanda, 1998, para..504.).

As regards the second part of the formulation, there is some uncertainty caused by the presence of, conditionally speaking, a psychological element. It refers to mental pain or mental injuries. The term "mental harm" is included in the Convention on Genocide at the request of China. Pointing to the practice of using drugs and other suggestive psychological substance by Japanese occupation forces against the Chinese people during the Second World War, representatives of China insisted that this form of acts are included in the concept of genocide. The proposal was partially accepted, and in paragraph (b) of Article II, in addition to serious physical injuries, mental injuries were added. However, in the absence of precise criteria it can be difficult to identify genocidal acts from such a generalized formulation (Avramov, 1992, pp. 82-83.). Mental disorders can occur in different ways, by means of torture, political indoctrination rather than just using opiates. In any case, not every type of physical or mental harm constitutes the material element of genocide. It must be sufficiently severe to cause destruction of the group, in terms of destruction as foreseen by the Convention i.e. physical and biological destruction.

\section{Deliberately inflicting on the group conditions of life calculated to bring about its physical destruction in whole or in part}

This is about a set of manners of destruction by which the perpetrator of genocide "does not immediately kill members of the group", but whose ultimate goal is the physical destruction of the group, such as starvation, systematic expulsion from homes, reducing the level of health services below the minimum level etc. The term "destruction", interpreted in terms of the ultimate goal, and the term "should" as an element of premeditation, or direct intent (dolus directus), indicate the type of conditions that solely bring about physical destruction. All others, which do not produce physical destruction as the final 
result, or which in terms of intention do not qualify as having enough capacity to produce such an outcome, cannot be considered genocide. The difference between the "killing of members of the group" and this method of physical destruction comes to the temporal dimension of the occurrence of lethal consequences. In the case of "killing members of the group", the act of destruction is accompanied by the material act and coincides with it, while "intentionally subjecting to conditions which would cause physical destruction of the group", the act of destruction is "deferred", therefore it does not coincide temporally with the act of execution.

\section{Measures intended to prevent births within the group}

The third form of physical exposure of destruction, "measures intended to prevent births within the group" is a typical form of the so-called biological genocide. The Convention provides that the crime of genocide may have been committed by biological extermination of the born, as well as the unborn members of the group (Convention on the prevention and Punishment of the Crime Genocide, Article II (d)) Acts which prevent biological reproduction groups are difficult to classify but it is generally accepted that these may include sterilization, genital mutilation, birth control in the group, the ban on marriage and the like. In Prosecutor v. Akayesu, the said act includes "sexual mutilation, the practice of sterilization, forced birth control, separation of the sexes and prohibition of marriages" (Trial Judgement, ICTR-96-4-T, International Criminal Tribunal for Rwanda, 1998, para. 507.).

The words "intended to" suggest that mere subjective tendency to prevent births is sufficient to constitute actus reus of the crime. In that sense, Kreß believes that measures must be objectively capable of preventing births (Kreß, 2006, p. 843.). According to him, words "imposing a measure" require that the act has been initiated (that the planning stage has been left) (Kreß, 2006, p. 843.). The wording, however, does not require that the intended result of birth prevention has actually been achieved (Kreß, 2006, p. 843.). For genocide to exist, it is not required to have proof that the perpetrator had chosen the most efficient method to achieve annihilation of the targeted population (Trial Judgemen, International Criminal Tribunal for the former Yugoslavia, 2001, para 36.). "In a sense, this indicates that all crimes of genocide should be better characterized as an attempt to commit genocide." (Trial Judgemen, International Criminal Tribunal for the former Yugoslavia, 2001, para 36.). Otherwise, the genocide could be prosecuted only when the group is actually annihilated, which is contrary to the objective of the relevant international instruments.

This form of genocidal acts, in the context of conventionally recognized ways of committing genocide, physical and biological, is characterized by the unreliability in achieving the targeted effects or intention of destroying the group. On the one hand, mass sterilization of the group can lead to the future destruction of the group, but on the other hand, this kind of genocidal act allows the element of chance that the group might not be destroyed completely and all at once. In any case, it should not be brought into connection with the practice of family planning, which can be legitimately carried out within national boundaries in the form of national programs and plans to define population policies, providing a complete non-discrimination. 


\section{Forcibly transferring children of the group to another group}

"Forcibly transferring children of the group to another group" does not represent a form of physical and biological destruction in the full sense. It refers more to cultural or sociological genocide, the forms of genocide which the Convention did not accept. It is included in the Convention as a compromise compensation for those requirements in favor of adoption of the concept of "cultural genocide". Ultimately, as understood by its authors, "forcible transfer" as a surrogate of cultural genocide, should and could, under certain conditions, bring about physical or biological destruction of the group.

In the grammatical interpretation, it does not seem that the transfer of children is carried out with the intention to annihilate them. Such a transfer would constitute an act of genocide only if the intent of the perpetrator was to annihilate these children as part of a broader intention to completely or partially annihilate the group to which the children belong. In the practice of the ICTR the initial action of this material act of genocide is not limited exclusively on the notion of "transfer", but is also extended to the "threat and trauma that lead to the forcible transfer of children from one group to another". (Trial Judgement), ICTR-96-4-T, International Criminal Tribunal for Rwanda, 1998, para.509.). In certain situations, transferring children can seem like a way to save a part of the group from physical destruction, regardless of it being carried out in conditions that are associated or strongly indicate the intention to commit genocide against the group to which the children concerned belong. Such an example would be a case of transferring children from ethnically mixed marriages when the salvation for a child or a group of children is seen in that part of their being which the perpetrator considers "pure blood".

The Convention does not define the meaning of the term "children" nor was this issue discussed by the preparatory bodies in the course of drafting. At first glance, it seems that this deficiency may not be crucial to understand the problem. The current international instruments in the field of children's rights, (Convention on the Rights of the Child, UN Doc. A/RES/44/25, annex, art. 1) as well as the vast majority of national legislations worldwide contain almost identical statutory provisions under which the legal boundary between children and adults is the age of 18. "The elements of crimes" of the International Criminal Court (hereinafter ICC) states that "the perpetrator knew or should have known" that a person is under the age of 18. (Rome Statute, Article 6 (f)) However, the adoption of this general standard of qualification of legal division of human beings to juveniles and adults does not solve the issue of perception of the acts of genocide contained in paragraph (d). The "forcible transfer" when it comes to the constitution of the crime of genocide, may have different effects on children of different ages. There is a big difference in the mental and psychological set of a 5-year old and that of, say, 12-year old child, and this fact can have a crucial impact on the perception of effects of forced transfer. For example, younger children forcibly transferred from one group to another can easily, over a period of time, lose the cultural identity of the group to which they belong by birth. Growing up in a different group, these children would speak their language, participate in cultural activities and practiced its religion. However, things are quite different when it comes to "older children". It is unlikely that these children would want to make a definitive break with the cultural history that binds them with their genetic parents. If, in order to constitute an act of genocide, the "forcible transfer of children" requires particularly serious consequences for the future viability of 
the group as such (Report of the International Law Commission, 1996, p. 92.) can such a sequence of events be considered as genocide as defined in paragraph (e) of article II of the Convention? From a purely legal point of view it would not be possible. This brings a logical question - what is the limit (age or psychosomatic) that is essential in order to constitute an act of genocide of forced transfer, which qualitatively separates a young, mentally immature and incompetent human being from adult, self-conscious and legally competent human being? Is it $16,18,21$ or some other age and can we rely on stable quantitative criteria? It seems impossible to set up an ideal system in this regard. Although not prescribed by the Convention, the genocidal act of "forcible transfer" only makes sense in relation to the relatively young children, (Schabas, 2000. p. 176.) so the limit of 18 years of age seems too high.

Physical and biological capacity of annihilation contained in the formulation in paragraph (e) of article II of the Convention calls for restrictive interpretation, and should be concerned only with cases involving fatal consequences stemming directly from physical and mental injuries, as side effects of "forcible transfer".

\section{Relation between actus reus and mens rea of genocide}

The above discussed and material acts become the acts of genocide only under strictly defined conditions. Firstly, there must be intent to destroy the group in whole or in part. Acts that result in the same consequences but which are not accompanied by the intention, do not fall under the definition of genocide. The intention must be directed to the group as the main object of genocide. The lack of intent "reiterates" the quality of the criminal act to the level of an ordinary crime or homicide. Secondly, the intention must be directed to the "national, ethnic, religious and racial groups" and not on the political, social, economic or any other group not defined by the Convention as a "protected group". And thirdly, annihilation must be directed to the group "as such". In terms of the Convention on Genocide, the word "as such", in terms of national, ethnic, racial or religious groups, is a qualification of character and refers to the requirement that the intended annihilation must be aimed directly against the group as a protected group. The International Court of Justice in the case brought by Bosnia and Herzegovina against Yugoslavia (Serbia and Montenegro) noted that "genocide, as defined in Article II of the Convention, comprises "acts" and "intent". It was well established that the acts - "(a) Killing members of the group; (b) Causing serious bodily or mental harm to members of the group; (c) Deliberately inflicting on the group conditions of life calculated to bring about its physical destruction in whole or in part; (d) Imposing measures intended to prevent births within the group; and (e) Forcibly transferring children of the group to another group" - themselves include mental elements (ICJ, Bosnia and Herzegovina v. Serbia and Montenegro, Judgment, 2007. note 8, par. 186.). Therefore, all material acts of genocide committed individually must be accompanied by a general purpose, covered by the umbrella sentence of Article II of the Convention, "to destroy in whole or in part a national, ethnic, racial or religious group, as such". To constitute a crime of genocide, it suffices to take any of the actions listed in Article II "with clear intention of bringing a total or partial destruction of the protected group as such." (Report of the International Law Commission on the work of its forty-eight session, May-July 1996, note 111, p.102, 
para. (b)). And vice versa, "to prove specific intent, it must be established that the said acts were on the one hand directed against the targeted protected group, and on the other hand that they were committed with the intention to completely or partially destroy the group as such."

It seems that the mens rea contained in the umbrella reference of Article II of the Convention, has a "stronger" intention capacity, in terms of the degree of culpability, compared to mens rea that accompanies the acts of genocide. The words "with intention to" offer more than a simple repetition that genocide was a deliberate crime. On the other hand, the level of the required genocidal intent varies from case to case and is not the same for each of the listed material acts of genocide. Paragraphs (a) and (b) include the ultimate result, so special intention is implied in itself. The perpetrator must have a specific intent to achieve the end result. The crime of murder (paragraph a) requires a specific intent to kill the victim. Also, in "serious violations of physical and mental integrity" this type of intent is included. On the other hand, the content of paragraphs (c) and (d) does not refer to acts or actualization of intentions in the form of concrete results. In these paragraphs the genocidal intent suggests the introduction of additional elements of conscious will, such as "deliberately" and "necessary". In the case of "being subjected to conditions of life..." it must be "calculated" to bring about physical destruction in whole or in part", while "measures to prevent births..." must be specifically aimed at preventing births within the group. "Forcible transfer of children..." in paragraph (e) does not bear in itself the obvious requirement of specific genocidal intent.

Overall, the "intent to destroy" the protected group as such requires specific intent, dolus specialis, as a condition inherent to genocide, while mens rea of material acts of genocide may exist in the form of direct intent.

\section{Conclusion}

The Convention on Genocide identifies the model of destruction, in paragraphs a, b, c, d and e of Article II, clearly reducing it to its biological and physical aspects, and does not adopt the concept of cultural genocide. A strict application of the principle of nullum crimen sine lege in the interpretation of provisions of the Convention does not support the expansion of the scope of genocidal destruction outside the given physical and biological framework. Therefore, in accordance with these acts, genocide is tantamount to physical and biological destruction of the group.

Physical genocide is specified in paragraphs (a), (b), (c), while the biological genocide is covered by paragraph (d). Prima faciae, only the "Forcible transfer of children" in paragraph (e) does not quite fit into the envisaged physical and biological determinant of genocide. In the case of "killings of members of the group" (paragraph a), and "being subjected to conditions of life..." (paragraph c) things are self-evident. Here is a typical form of biophysical destruction. Discussions by the UN bodies, regarding the formulation of paragraph (b) on "severe physical and mental injuries" were also conducive to establishing a primarily physical form of genocide. As for the provision the "imposition of conditions of life calculated to bring about the destruction of the group" it can only be conditionally said that it meets the standards of accepted forms of destruction, while the "forcible transfer of children" as an act of material destruction, remains controversial. 
The conventional concept of the model of destruction, which is based on physical and biological determinants of genocide, raises the question of the necessity of mutual complementarity between the concept of destruction, which exists in the first part of the said Article, as part of the intention and, on the other hand, the material acts of genocide, contained in its second part. In other words, if the intention of the agent of violence is to bring about destruction of the protected group by means of attacking its cultural and economic prerogatives, not by direct physical destruction of its members, will such a behavior be treated as genocidal or not? Will spontaneous and unorganized mass killings of members of the targeted group be deemed as a genocidal act in case when "killing", as such, is not the intended form of achieving genocidal intent? Stricto sensu interpretation of Article II of the Convention yields a negative answer. Historical facts, however, indicate that the almost complete disappearance of Native American people and Aboriginal communities in Australia occurred mainly as the result of a planned and long-term devastation of cultural, economic and social conditions of life, and not as a result of specific actions aimed at their physical destruction. Mass killings, which undoubtedly took place, did not reflect a clearly defined genocidal intent to bring about physical destruction, but were largely carried out in the form of sporadic massacres devoid of factual and logical continuity that suggests the existence of an ultimate plan. However, the ultimate effect of this "silent" or "missionary" genocide had the same devastating effect of modern day genocide. The issue does not carry only a legal but also a moral dimension. Condemnation of genocide at the international level should not be obstructed by a mere fact of strict discrepancy between the intention and the manner of execution of such acts, even when the ultimate quantitative and qualitative parameters point to the obvious conclusion about its existence or execution. The spirit and intent of the Convention on Genocide appears to allow such a possibility. This could be confirmed by extensive interpretation of provisions of Article II, which, in our opinion, carries the essence of solution to this logical absurdity. Namely, observed from the perspective of formal positioning of the intention of destruction, (the umbrella structure of Article II), with respect to material acts of genocide, a conclusion may be drawn on the existence of domination of the legal effect of the first, relative to the second element of the crime. Provided a broader interpretation of the meaning of intention of destruction, this could mean that the murder of members of the group, which does not strictly represent the intended form of committing genocide (killing members of the group, paragraph a) also falls under the acts of genocide even if they are carried out as part of a genocidal plan where mens rea is marked by economic and social logic of destruction. Naturally, extensive interpretation of the corresponding latent capacity of the Convention should not go beyond reasonable limits prescribed by the principle of legality and the rules of interpretation of treaties under the Vienna Convention of 1969.

\section{References}

Aksar, Y. The "victimized group" concept in the Genocide Convention and the development of international humanitarian law through the practice of ad hoc tribunals Journal of Genocide Research, 2003. 
Avramov, S, Genocid u Jugoslaviji u svetlosti medjunarodnog javnog prava, Beograd, 1992.

Avramov, S, Kreća, M. Medjunarodno javno pravo, Belgrade, 1999.

Chalk, F. and K. Jonassohn, The History and Sociology of Genocide, New Haven, 1990.

Straus, S, Contested meanings and conflicting imperatives: a conceptual analysis of genocide, Journal of Genocide Research, 2001, 3/3.

Schabas, A. W, Genocide in International Law-The Crimes of Crimes, Cambridge, 2000.

Lemkin, R, The Letter proclaimed in Executive Sessions of the U. S. Senate Foreign Relations Committee, Historical Series 781-805, 1976.

Lemkin, R, Axis Rule in Occupied Europe, Washington, 1944.

Vabres, D. De, Les principes modernes du Draft Penal International, Paris, 1928.

Drost, P, The Crime of State, Leyden, 1959.

Straus, S, Contested meanings and conflicting imperatives: a conceptual analysis of genocide, Journal of Genocide Research, 2001, 3/3.

Schabas, A. W, An introduction to the International criminal Court, Cambridge.

Schabas, A. W, Genocide in International Law-The Crimes of Crimes, Cambridge, 2000.

Fein, H, Genocide: A Sociological Perspective, London,1993.

Kpeß, C. The Crime of Genocide under International Law, International Criminal Law Review, 2006.

Triffterer, O, Genocide, Its Particular Intent to Destroy in Whole or in Part the Group as Such, 2001.

J. Jones / S. Powles, International Criminal Practice, translation, Belgrade, 2005.

ICJ, Case conserning the application of the Conventipon on the prevention and punishment of the crime of genocide, Bosnia and Hertyegovina v. Serbia and montenegro, Judgment, 26. february 2007.

Convention on the prevention and Punishment of the Crime Genocide, https://treaties. un.org/doc/publication/unts/volume\%2078/volume-78-i-1021-english.pdf

Draft Convention for the prevention and Punishment of Genocide presented by the Secretary-General, 1947.

Report of the Commission International Law Commission on the work of its forthyeight session, may-july 1996

Convention on the Rights of the Child, UN Doc. A/RES/44/25.

Prosecutor v. Jean-Paul Akayesu (Trial Judgement), ICTR-96-4-T, International Criminal Tribunal for Rwanda (ICTR), 2 September 1998, available at: http:// www.refworld.org/docid/40278fbb4.html [accessed 1 April 2016].

The Prosecutor v. Radislav Krstic (Trial Judgement), International Criminal Tribunal for the former Yugoslavia (ICTY), 2 August 2001, available at: http://www.refworld. org/docid/414810d94.html [accessed 1 April 2016]

Vienna Convention on Law Treaties, Source: International public law - A collection of documents, Belgrade, 2005. 